\title{
The 'oldest dated document of the Cairo Genizah' (Halper 331): The Seleucid era and sectarian Jewish calendars
}

\author{
Eve Krakowski (Princeton) and Sacha Stern (UCL)
}

The vast trove of documents discovered in the late $19^{\text {th }}$ century in the genizah (storage) of the Ben Ezra synagogue in Fusțāt, old Cairo, hardly needs an introduction. Most of the texts and documents are written in Judeo-Arabic or Hebrew, and date from between the $10^{\text {th }}$ and the $13^{\text {th }}$ centuries. In this article, however, we shall consider a much earlier document, possibly from the Cairo Genizah, which dates to the latter part of the $9^{\text {th }}$ century. It is the text of a legal document in Hebrew and Aramaic, which has been identified in the past as a ketubbah (marriage contract). All that survives of it is its opening, which contains a series of introductory formulae and a detailed date. As we shall see, this date is very problematic; it raises questions about the document itself, as well as about the Jewish calendar of which, in the $9^{\text {th }}$ century, relatively little is known. ${ }^{1}$

The fragment is held in the library of the Herbert D. Katz Center for Advanced Judaic Studies, Philadelphia, where it is shelf-marked Halper 331. The entry of the University of Pennsylvania Library catalogue, which incorporates the Katz Center library, reads as follows:

Book. 1 fol.: fragment; incomplete, cropped beneath final line.

Parchment 14 x $8.8 \mathrm{~cm}$ black ink ruling method: recto (original document), drypoint, stylus lines visible, large margin on interior side (...)

The oldest dated Genizah document. A draft of a ketubah [sic], in which the writing is interrupted after the date in the seventh line, probably because the day in the month is mistaken: 17 Tishre 1183 Seleucid year. The parchment has been cut off beneath this final line $(\ldots)^{2}$

\footnotetext{
${ }^{1}$ This article engages with a few of François de Blois' many intersecting academic interests: Aramaic language, the early medieval Near East, and calendar and chronology. Particularly relevant, in this context, has been François' work since 2010 in the Leverhulme and ERC research projects at UCL on ancient and medieval calendars, in which he researched, inter alia, some Muslim, Arabic-language treatises on the Jewish calendar. As François has shown, the earliest of these treatises, by the mathematician and scholar Muhammad b. Mūsā al-Khuwārizmī, was composed apparently in 823/4 CE and represents the earliest evidence of the rabbinic calendar in its final, fixed form (see F. de Blois, 'Some early Islamic and Christian sources regarding the Jewish calendar, $9^{\text {th }}$ to $11^{\text {th }}$ centuries', in S. Stern and C. Burnett (eds.), Time, Astronomy, and Calendars in the Jewish Tradition, Leiden: Brill, 2014, pp. 65-78). It remains unclear, however, to what extent this calendar was accepted and used in this period as definitive; the Exilarch's letter of 835/6, for example, indicates that this fixed calendar was not always heeded (reference below, n. 6). This present document, from the later $9^{\text {th }}$ century, may shed further light on this little known period in the history of the Jewish calendar. Research towards this paper was carried out by Sacha Stern in the framework of the ERC project 'Calendars in Antiquity and the Middle Ages' at UCL. An earlier version of this paper was presented at an ERC team meeting, and a later draft was read by Nadia Vidro; Gideon Bohak subsequently provided helpful advice. We are grateful to these colleagues for their comments.

${ }^{2}$ https://franklin.library.upenn.edu/catalog/FRANKLIN 9934790513503681. A good quality image of the fragment can be viewed at http://openn.library.upenn.edu/Data/0002/html/h331.html and https://medium.com/@judaicadh/10-marriage-contracts-from-penns-cairo-geniza-collection-14ae241fd5ec (accessed 1 July 2018). An edition and brief commentary on our fragment was published by S. D. Goitein. 'Four Old Marriage Contracts from the Cairo Geniza', Lěšonénu: A Journal for the Study of the Hebrew Language and Cognate Subjects 30:3, 1966, pp. 197-216, on pp. 199-200 [Hebrew].
} 
Much of this description should be qualified: the text is likely not a draft, is not necessarily a ketubbah, and is not really the 'oldest dated Genizah document'. Indeed, we must begin by noting that it is uncertain whether Halper 331 is a 'Genizah document' at all. In his catalogue, which has determined the shelf-marking of the (now) Herbert D. Katz Center Library, Benzion Halper identifies the fragment as belonging originally to Amram's collection, ${ }^{3}$ on which he writes in his preface:

\section{The Honorable Mayer Sulzberger, Professor David Werner Amram ... [et al.]} subsequently [after 1891] obtained their collections, which presumably hail from the Orient (most of the fragments seem to be from the Cairo Genizah), from various dealers. $^{4}$

The provenance of our fragment is thus far from certain. Nevertheless, in spite of Halper's caution, Halper 331 - like the other texts in this collection - has widely been assumed to be from the Genizah, presumably because the Genizah was the only known source of fragments of this nature that were discovered and marketed around the turn of the $20^{\text {th }}$ century. Yet even if this assumption is correct, its preservation in the Genizah does not mean that the document itself came from Fustạt; either Halper 331 itself, or the text it contains, may originate from somewhere east of Egypt and Palestine.

The date of the fragment, according to the University of Pennsylvania Library catalogue (based on the entry in Halper's catalogue), is ' 17 Tishre 1183', but this is incorrect. The text actually reads 1182 . As a Seleucid year, it is equivalent, therefore, to 870/1 CE. According to the catalogue, this makes it the 'oldest dated Genizah document'.

The quest for the 'oldest', or 'oldest dated', document in the Cairo Genizah has a long history in Genizah scholarship..$^{5}$ Almost all the dated documents preserved in the Geniza were produced during the tenth century or later. Only a tiny handful of documents explicitly dated to the ninth century, maybe no more than five, have been identified. Among these, Halper 331 has thus far held pride of place, because the other four are obviously later copies written after the date they mention. These include the text of an Aramaic bill of manumission dated $827 / 8 \mathrm{CE}$, in a fragment of what appears to have been a book containing Palestinian-

Rabbanite liturgy and document formularies; a fragmentary copy of a letter written in 835/6 by the exilarch in Iraq about calendrical matters; another Palestinian-Rabbanite formulary, this time for a bill of divorce, copied from a bill dated 872/3 in Jerusalem; and the beginning of a partnership contract copied into a codex, again evidently for use as a formulary, dated 875 or 876.6

\footnotetext{
${ }^{3}$ B. Halper, Descriptive Catalogue of Genizah Fragments in Philadelphia, Philadelphia: The Dropsie College for Hebrew and Cognate Learning, 1924, p.175.

4 ibid. 9-10. He goes on to explain that Amram's collection was purchased by the Dropsie College, presumably at some point before the 1920s. The Herbert D. Katz Center is the successor to Dropsie College and now owns its library. I am grateful to Arthur Kiron and Bruce Nielsen, Librarians at the Katz Center, for checking the library archives and verifying this information.

${ }^{5}$ For an apt survey up to his time of writing, see S. Hopkins, 'The Oldest Dated Document in the Geniza?', in S. Morag, I. Ben-Ami, and N. A. Stillman (eds.), Studies in Judaism and Islam Presented to Shlomo Dov Goitein on the Occasion of his Eightieth Birthday, Jerusalem: Magnes Press, 1981, pp. 83-98; and more recently, J. Olszowy-Schlanger, 'Les plus anciens documents datés de la Guenizah du Caire: lectures et relectures', LivretAnnuaire de l'EPHE, Sciences Historiques et Philologiques, 20 (2004-5), pp.47-50.

${ }^{6}$ Bill of manumission: T-S J 3.16 + T-S NS 211.1, ed. M. Margoliouth, Hilkhot Ereș Yisra'el min ha-Genizah (Jerusalem, 1973), 27-31. Exilarch's letter: T-S 8 G 7.1, ed. S. Stern, Calendar and Community: A History of the Jewish Calendar, $2^{\text {nd }}$ century BCE $-10^{\text {th }}$ century CE, Oxford: Oxford University Press, 2001, pp. 277-83. Bill of
} 
We will suggest below that, even putting aside the question of its provenance, Halper 331's current claim to distinction as the oldest original document preserved in the Genizah is likely unwarranted. Like the other three early legal documentary texts just mentioned, it is more likely a formulary copied from the original ninth-century text. Paleographically, however, it seems possible that the copy was made relatively soon after 870 or 871 . Halper 331 resembles a subset of Hebrew-script documents on papyrus written in a crude, seemingly unlearned hand, which are typically assumed to date before the tenth century. ${ }^{7}$

Whenever it was set to parchment, the early date of the text itself gives this fragment particular importance. Not only do very few medieval Jewish documents this early survive; but the formulary and the detailed date featured in Halper 331 are both unusual and significant, in ways that have not been fully appreciated in previous scholarship.

\section{$\underline{\text { Text and translation }}$}

The document's main surviving text consists of seven lines of introductory formulae: a series of protective formulae in Hebrew (11.1-4), followed by the beginning of a dating clause in Aramaic (11.4-7).

A slightly jumbled biblical verse appears in the margin to the right of the main text: Psalms 135:21, but with the word הללויה (Hallelujah) misplaced near the beginning of the sentence rather than at its end. Although this marginal insertion is slightly fainter and more cursive than the main text, it appears likely to be of the same hand. The author of the insertion has made use of the ink ruling (referred to in the catalogue entry, above quoted), which extends across the whole width of the fragment, up to and including the margin. Although the marginal text only approximately follows the lines of the ruling, it is not much worse in this respect than the main text. Since the main text and the marginal text share the same ruling, we have laid out our text edition and translation in the form of a grid. It must be emphasized, however, that the marginal text is to be read downwards; there is no relationship between marginal and main text that happen to be written on the same rows.

\begin{tabular}{|r|r|}
\hline ברוך & \\
\hline
\end{tabular}

divorce: T-S NS 308.25, ed. Margoliouth, ibid., 121. Partnership contract: T-S C 2.17, ed. G. Weiss, 'A Testimony from the Cairo Geniza Documents: Son-in-Law, Mother-in-Law Relations', Jewish Quarterly Review, 68(2), 1977, pp. 99-103, in p. 99 and n.1. Another ketubbah, composed in Iraq, may date from the late $9^{\text {th }}$ century: TS Ar. 38.11. Hopkins ('The Oldest Dated Document in the Geniza?', pp. 92-3) thought that this ketubbah might have predated Halper 331; but Olszowy-Schlanger ('Les plus anciens documents datés de la Guenizah du Caire') showed that this was based on a misreading of its date, which is $13^{\text {th }}$ century SE, thus between 889 and 988 CE (on this document, see also N. Golb, 'A Marriage Deed from 'Warduniā of Baghdad,' Journal of Near Eastern Studies 43.2 (1984): 151-156).

${ }^{7}$ As Goitein noted in his edition of the document. No one has yet conducted a full paleographic analysis of these fragments. Preliminarily, however, Halper 331 may readily be compared, for example, to several other documents in the same collection: Halper 33, 39, 46, 70. References to many of these papyri are collected in C. Sirat, Les papyrus en caractères hébraïques trouvés en Egypte (Paris, 2001).

${ }^{8}$ The reading of these two words is uncertain (in particular, the letters resh and zayin) and yields a problematic text, since it makes little grammatical sense for the scribe to have spelled קרן plene in this way; but it is the only possible reading. Goitein reads: בין כאן בין [.]"פה, which makes little sense in Hebrew or in context (in spite of Goitein's attempt to explain it as an extension of the introductory blessings to other parts of the world), and 


\begin{tabular}{|c|c|}
\hline במזל גבוה יהיה לנו ולכל & ייי הללויה \\
\hline ישראל9 כין הוה במעלי & מציון \\
\hline שבתא דהוא שבעת10 & שיכון11 ש \\
\hline עסר בתישרי ששנת12 & ירושלים13 \\
\hline אלפא ומאה ותמנן ותרתן14 & \\
\hline
\end{tabular}

\begin{tabular}{|l|l|}
\hline & With a good sign for us and for all Israel, \\
\hline Blessed is & at a good hour, with an upright horn, \\
\hline the Lord, Hallelujah, & (under) a high constellation, ${ }^{15}$ (so) may it be for us and for all \\
\hline from Zion, & Israel! So it was: on the eve \\
\hline Who dwells & of Sabbath, which was the seven- \\
\hline in Jerusalem. & teenth of Tishri of the year \\
\hline & one thousand one hundred and eighty two \\
\hline
\end{tabular}

The formula כין הוה ('So it was') identifies our text, minimally, as a legal document. This phrase (and variations on it) are among several conjunctions that appear ubiquitously and interchangeably in the opening formulae of Genizah Hebrew legal documents (such as also כי איך (כ) These conjunctions introduce the legal transaction (or more precisely, the testimony about a legal transaction) that the document serves to record. In Genizah documents they usually mark the beginning of the operative section but sometimes, as here, appear at the start of the dating clause.

The date would not have ended here. After the number of years, at the end of the text that is extant, the term שנין would probably have appeared ('years' - very normal in Aramaic dates, albeit pleonastic with ששנת, 'of the year', on the penultimate line), followed by one of the standard phrases clarifying which era was used, possibly with the phrase למנינא דרגלינא,

is not the correct reading of the manuscript; Goitein misread, in particular, the letters qof. The phrase בקרן ז זקופה is attested in liturgical poetry (Shelomo ha-Bavli, Yotzer (Zulat) for Passover - later $10^{\text {th }}$ century), whilst the fuller phrase קרץ זקופה ומזל גבוה appears in the opening of a legal query addressed to Shemarya b. Elhanan (Fustat, ca. 980-1011: T-S Misc. 35.17r I.2; erroneously transcribed in Simḥa Assaf, Teshuvot ha-Ge'onim, Jerusalem 1942, 113-15).

${ }^{9}$ The Hebrew opening stops here; the body of the contract or deed, in Aramaic, begins from this point.

${ }^{10}$ The ayin is closed at the top, but this appears to be the reading. The last letter is taw (pace Goitein), even though a heh is expected (his reading). Goitein suggests that the scribe first wrote שבסר, as is normal in Aramaic for 'seventeen', but then changed it to a form closer to Hebrew and Arabic. We do not see evidence of this conjecture.

${ }^{11}$ An error for שכוכין, שכן plene spelling of (see Psalms 135:21). The scribe's disposition for plene spelling is also evident in line 4 of the main text, with the word כין, and possibly also in line 2 (see above). As noted above, the wללויה in the marginal text is out of place and belongs at the end of the verse.

12 So Goitein; for שלשנת.

${ }^{13}$ Halper (Catalogue) reads (!)ירושלום, but this is unjustified.

ותמנן 14 : the penultimate nun is pointed with a Babylonian qamatz (as Gideon Bohak pointed out to us). ותרתן: so Goiten; this seems like the only possible reading, although most of the resh is faded, and the final nun remains very uncertain and could be missing altogether from what remains of the fragment; if it is there, it would be on the fragment's very edge (I have examined the original, and have not been able to ascertain this). Halper reads ותלת, 'and three', though acknowledging that the word is 'slightly obliterated', and expressing the view that this 'is immaterial to the ascertaining of an approximate date'. Halper's reading would date the contract to one year later, i.e. $1183 \mathrm{SE}$, as is also assumed in the catalogue entry quoted above; but this reading is incorrect, as the base of the third letter does not have the shape of a lamed, and there is no trace of its ascender.

15 i.e. a favourable astrological sign. 
'according to the customary reckoning, ${ }^{16}$ and then an account of the testimony or transaction that occurred on this date.

The continuation of the text was not written on the verso, as this side was originally left blank (although ruled, like the recto). The verso was later filled in with a totally different text in Jewish Babylonian Aramaic, written width-wise across the ink ruling, and filling the contours of the torn fragment; the catalogue entry describes it as 'a Midrashic passage in Aramaic about the humility of Adam among the creatures'. We have not been able to identify this text with any further precision; because of its later date, this text is not part of the present study. If, as will be presently argued, our fragment was originally part of a codex, and the legal document continued on a facing page, it may be more correct to refer to the legal document side of the fragment as 'verso'.

\section{Manuscript and context}

The very first word of the catalogue entry, quoted above, determines that the fragment was not an actual document, but rather part of a 'book', i.e. into which the document had been copied. That this folio belonged originally to a book is not, however, self-evident. Goitein invoked as proof, but without elaboration, a small flap of parchment that is attached along the top of the left side of folio. This flap, indeed, could be explained as the remnant of the folio's facing page, or as a tab that served to stick our fragment into a codex. However, this proof is not as strong as Goitein makes out: this flap could indicate, more minimally, that this fragment originally belonged to a larger sheet of parchment that was folded and then torn across the fold, without necessarily being part of a codex.

Stronger evidence that the fragment was originally part of a codex can be drawn from the distinctively book-like layout of the text: in particular, the very wide outer margin on the right (although additional text has been written into it), ${ }^{17}$ and a margin at the bottom of the fragment. The bottom part of the fragment is partially torn (according to the catalogue entry: 'cropped beneath final line'), but enough remains to show that there was originally a full margin, with enough space for the scribe to write an extra line if he has so wished. Goitein claims that the scribe stopped writing because he made an error in the date (and this claim is replicated in the catalogue entry). The date is indeed problematic, as we shall see, but it is not necessarily erroneous. It is far more likely that the scribe stopped writing before the end of the sheet because the conventions of codical layout prevented him from writing further below.

Another consideration is the size of the fragment. The lower margin, or what survives of it, shows that the fragment is not truncated at the bottom, but rather originally ended there. Given the amount of text that presumably still needs to follow (the end of the date, the place name, and then the rest of the contract or deed), the text is likely to have continued over several other pages, and the scribe must have been aware of this well in advance. The small size of our fragment, with space for only seven short lines of text, is a further indication that it could not have been intended as the contract itself. Legal documents are normally written on single folios, not on many, consecutive book-size pages. All this draws us to the

\footnotetext{
${ }^{16}$ As for example in Friedman, Jewish Marriage in Palestine, vol. 2 no.17, and in Hebrew, no.50; these phrases are very common in the dating formulas of contracts and other documents.

${ }^{17}$ The catalogue entry, quoted above, refers to this large margin on the right as 'on interior side', but it is more likely to be the outer side, given that the flap is on the left.
} 
conclusion that this text is a copy of a legal document, rather than the document itself, and that it was most probably inscribed in a codex.

According to the catalogue entry, this fragment was the 'draft' of a ketubbah. It is difficult to understand, however, why a draft would have been written into a codex. Goitein lays down instead, but again without much argument, that this codex must have served as an official register of the court or of the Jewish community. Judging from all other such registers available to us, however - with the caveat, of course, that these date from later periods - it would be unusual for the full text of a ketubbah, including opening formulae irrelevant to the essentials of the contract, to have been inscribed into a court record in this way. We would expect instead a shorter summary that captures merely the date, the names of the parties and witnesses, and the general and special stipulations of the marriage contract. ${ }^{18} \mathrm{We}$ also have no way of knowing whether this text came from a locale where Jewish court registers were kept as early as the $9^{\text {th }}$ century; if it is from Fustạt, for example, this would be doubtful. ${ }^{19}$

A more likely suggestion is that the text of this legal document was copied into a codex as part of a formulary. In most formularies, the ephemeral details of the contracts such as specific names and dates are left blank, or filled with blank terms such as 'so-and-so'.

However, this is not always the case. Among the other document formularies preserved in the Genizah that contain a ninth-century date, ${ }^{20} \mathrm{~T}-\mathrm{S} \mathrm{C} 2.17$ offers the closest parallel to our text. It is the recto right (bottom half) of a parchment bi-folio containing the text of a contract of partnership, with the specific date of 17 Iyar, year 4635 from the Creation $(=875$ or 876 CE). ${ }^{21}$ Its presence in a bi-folio indicates clearly that it was part of a book. The text does not go beyond the date, but it must have continued on another page. That it was intended as an entry within a formulary seems clear from the heading, 'Partnership' (שותפות), that precedes it. The proximity of its date to that of our document $(870 \mathrm{CE})$ is striking. The similarity of this fragment to ours suggests very strongly that the text of our legal document might also have been included in a book as part of a formulary.

\section{The opening formulae}

As the catalogue entry makes clear, most scholars have assumed that the text of Halper 331 was not just a legal deed or contract but specifically a ketubbah, a marriage contract. ${ }^{22}$ At first glance, this identification appears obvious. Both the protective formulae with which Halper 331 opens, and the verse from Psalms inscribed in its right margin, parallel features that appear in many ketubbot from the Middle Ages and later. Yet the text's apparent

\footnotetext{
${ }^{18}$ As is the norm for entries of marriage and other contracts in later Genizah court registers, including the earliest known exemplar, from 933 in Damascus; see the next note.

${ }^{19}$ The earliest court notebooks preserved from Fusțāt date from the early $11^{\text {th }}$ century, and it is not clear whether there were standing Jewish courts there before this period; Eve Krakowski is currently working on a larger study devoted to this question. However, fragments do survive of an earlier court register from Damascus, produced in 933 and apparently devoted specifically to matrimonial contracts. See Friedman, Jewish Marriage in Palestine, nos. 53-55.

${ }^{20}$ See above, n. 6.

${ }^{21}$ This depends on which era from Creation was assumed. According to the 'western' or Palestinian reckoning (which is in dominant use today), the year 4635 would have corresponded to 874/5 CE. According to the 'eastern' or Babylonian reckoning, as first attested in the Babylonian Talmud, bAvodah Zarah 9b, the year 4635 corresponded to $875 / 6$ CE.

22 This identification was made by Halper, Descriptive Catalogue, p. 175, and taken for granted by Goitein, 'Four Old Marriage Contracts', as well as in the UPenn catalogue.
} 
familiarity is misleading. In fact, the specific clauses used in Halper 331- 'with a good sign for us and for all Israel, at a good hour, with an upright horn, (under) a high constellation, for us and for all Israel' — are unique.

This particular formulation is unknown from any other surviving text, ketubbah or otherwise. ${ }^{23}$ Nonetheless, the hundreds of ketubbot from Fatimid Egypt and Syria preserved in the Cairo Genizah - the earliest corpus of medieval ketubbot that we have-do contain several similarities to Halper 331 worth noting. The parallels are complex and require surveying in some detail. The earliest ketubbot preserved in the Genizah date to the tenth and early eleventh centuries, almost all from the $970 \mathrm{~s}$ and after. ${ }^{24}$ They belong to three distinct formulary traditions: Palestinian-Rabbanite, Iraqi-Rabbanite, and Qaraite. ${ }^{25}$ Each of these types includes one or more characteristic prologues - invocations, blessings, and biblical verses - external to the contract proper. These are usually placed, at least in part, as superscriptions above the main body of the text; the few surviving exceptions, whose layout resembles Halper 331 in including a prologue entirely in line with the main text, appear to be either drafts or formularies - a pattern that may further support our suggestion that Halper 331 was written as a formulary. ${ }^{26}$

The prologues vary by ketubbah type. Both Palestinian-Rabbanite and Qaraite ketubbot typically begin with an invocation of God's name, in Hebrew in Qaraite ketubbot and in Aramaic in Palestinian-Rabbanite ones. ${ }^{27}$ After this they diverge: prologues in Palestinian Rabbanite ketubbot are generally short, most often containing either a passage from II Chronicles 14:6 (יבנו ויצליחו', 'they built and prospered'), or else the variant phrase נעה ונצליח ('may we prosper in what we do'), ${ }^{28}$ whereas Qaraite preambles are often lengthy, comprising numerous biblical verses and often a messianic liturgical poem declaring God's imminent reestablishment of the Temple in Jerusalem and the ingathering of the exiles. ${ }^{29}$ Beginning in the 1030s, Qaraite ketubbot also feature clauses dating the marriage to 'the

\footnotetext{
${ }^{23}$ The phrase 'a good sign for all Israel' is found, however, in early rabbinic sources, with slight variations and in a variety of contexts (none of which, however, are documentary or legal): Mekhilta de-Rabbi Yishmael, Bah̆odesh 4; Genesis Rabbah 6:2 (ms Vatican Ebr. 30 fol. 7v); Babylonian Talmud, Shabbat 89a; and JTS ENA 1745 , fol.1v (on the latter see S. Stern, 'New light on the primitive rabbinic calendars: JTS ENA 1745', Journal of Jewish Studies 69 (2018) 262-79, arguing for an $8^{\text {th }}$-century dating). The phrase is then used in liturgical contexts in later medieval sources, already in tractate Soferim 19:10 (whose provenance and date are unclear). ${ }^{24}$ The few exceptions from the first half of the tenth century follow the Palestinian-Rabbanite tradition and thus, as will be detailed in the following paragraphs, do not contain parallel features to our document. These include the court record of betrothals and marriages from Damascus, 933, and the ketubbah produced in Qugandima in 945; see above, n. 19, and below, n. 54.

25 The first and third of these have received detailed scholarly attention in M. A. Friedman, Jewish Marriage in Palestine (which focuses on Palestinian-Rabbanite ketubbot and other marital contracts) and J. OlszowySchlanger, Karaite Marriage Documents in the Cairo Geniza (which focuses on Qaraite marital documents, including betrothal contracts as well as ketubbot). In contrast, very few of the Iraqi-Rabbanite ketubbot have been published.

${ }^{26}$ E.g., Bodl. MS Heb. d. 66.49v-50r (a Qaraite formulary, ed. Olswozy-Schlanger, Karaite Marriage Documents, no. 52); T-S $8 \mathrm{~J} 1.14$ (text of an Iraqi-Rabbanite ketubbah from Fusțāț, 1094, written as a draft or writing exercise).

27 See Friedman, Jewish Marriage in Palestine, 91-96; Olszowy-Schlanger, Karaite Marriage Documents, 135138. Some Palestinian-Rabbanite ketubbot contain minor variations, including Ezra 6:14 in place of II Chron. 14:6; see Friedman, ibid., 94.

${ }^{28} \mathrm{~A}$ few feature additional biblical verses and two later ketubbot (both from the 1080s) include lengthier preambles; see ibid., 95.

${ }^{29}$ Olszowy-Schlanger, Karaite Marriage Documents, 140.
} 
lifetime of' the current Qaraite nasi (Patriarch) and in some cases also to 'the lifetime' of the bride, groom, congregation, and 'all of Israel.' 30

Iraqi-Rabbanite ketubbot, in contrast, contain no invocation. Instead they feature one of three distinct prologue types that overlap only minimally with the Palestinian-Rabbanite and Qaraite ones. Two of these appear interchangeably in the tenth and early eleventh centuries: either a protective Aramaic formula asserting that the marriage will occur with 'a good charm and a perfect sign,' followed by the same citation from II Chronicles 14:6 found in

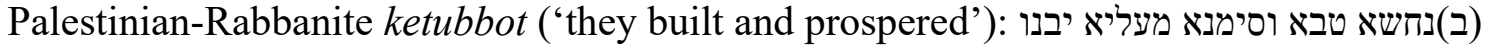
מצא אשה מצא טוב ויפק רצון :One who finds a wife finds goodness, and obtains favor., ${ }^{32}$ Beginning in the $1060 \mathrm{~s}$, both prologues began to be replaced by a third option, a longer Hebrew protective formula formulated as a poem, which declares that the marriage has occurred or will occur 'at an exalted hour, at a glorious time' and with rejoicing for 'the bride and groom and the whole congregation.' 33

These varying prologue types, found in dozens of ketubbot from the tenth and eleventh centuries, parallel Halper 331's formulae in several ways. Most obviously, the string of protective formulae that open Halper 331 resembles the protective formulae that open IraqiRabbanite ketubbot - both the earlier Aramaic versions (which like Halper 331 mention a propitious 'sign') and the later Hebrew ones (which like Halper 331 mention a propitious 'hour,' and which moreover direct their protective formulae at the bride and groom and 'the whole congregation,' similar to Halper 331 's reference to 'all Israel').

Yet other aspects of Halper 331 more closely presage the Qaraite ketubbah prologues. First, there is its citation of Psalms 135:21, 'Blessed is the Lord, Hallelujah, from Zion, who dwells in Jerusalem.' Although this is not a standard choice in Qaraite ketubbot - it appears among them only once, in an undated ketubbah formulary from Jerusalem ${ }^{34}$ —its use parallels the recurring messianic allusions to Jerusalem found in Qaraite ketubbot, reflected both in their frequent inclusion of biblical verses on the theme and in the relatively standardized messianic liturgical poem that appears in many of their prologues. Second, there is the twice-repeated

\footnotetext{
${ }^{30}$ On the nasi clause, see ibid., 153-4. In two Qaraite ketubbot from Egypt, written in 1036 and 1045, this series of 'lifetime' clauses begins with a protective formula declaring that the marriage will occur at a propitious time: נתחיל בשעת רצון מאל עליון בחיי אדנינו הנשיא... ובחיי הארוש והארושה ובחיי כל עדת ישראל (loct)

('let us begin at an hour of (good-)will from God the (most) High, in the lifetime of our lord the nasi...and the lifetime of the groom and bride, and the lifetime of the entire community of Israel'). Ibid., no. 5, and cf. no. 52. For other documents written before 1050 (or that are undated) and that include some version of this 'all Israel' clause, see ibid., nos. 4, 5, 8, 13, 51, and 54 .

${ }^{31}$ This formula appears in dozens of unpublished ketubbot. See, e.g., T-S 16.245 (1015), Bodl. Heb. a. 2/4 (1029), and T-S 20.7 (1050).

32 This formula is less common than נחשא טבא, etc., but appears in around a dozen ketubbot known to us. See, e.g., T-S 16.78, Bodl. Heb. b. 12/22.

${ }^{33}$ The earliest examples known to us are T-S 12.98 (dated sometime between 1058 and 1067) and Bodl. a.3/38 (1067). CUL Or. $1080 \mathrm{~J} 260$ (dated between 1068 and 1079) and later ketubbot include a longer version: בשעה מעולה ועונה מהוללה ושמחה וצהלה וחדוה וגילה ומילוי כל שאלה לחתן ולכלה ולכל הקהילה (10valted hour, at a glorious time, (with) joy, shouting, rejoicing, gathering, and the fulfillment of every request for the bride and groom and the whole congregation.' In the twelfth century, versions of this prologue began to include a rashut formula acknowledging the authority of the Head of the Jews, similar to the earlier Qaraite nasi clause; see Mark Cohen, Jewish Self-Government in Medieval Egypt, 266-267.

${ }^{34}$ CUL Or. 1080 13.52, ed. Olszowy-Schlanger, Karaite Marriage Documents, no. 51, which contains a marginal notation instructing scribes to begin a ketubbah written for a Levite with this verse.
} 
phrase 'for us and all Israel.' Although (as we have just noted) this formula resembles the references to 'the whole congregation' found in later eleventh-century Iraqi-Rabbanite ketubbot, the parallel is not exclusive; similar references to 'all Israel' appear also in the nasi clause found in Qaraite ketubbot beginning in the 1030s, three decades before the earliest Rabbanite examples. Although all three prologue types overlap in using variants of the phrase 'they built and prospered,' the Iraqi-Rabbanite and Qaraite prologues are thus closer both to each other, and to Halper 331, than are the Palestinian-Rabbanite ones. ${ }^{35}$

These parallels suggest that the Iraqi-Rabbanite and Qaraite ketubbah prologues developed from a common formulary tradition, to which Halper 331 offers a unique ninth-century witness. That these two ketubbah types should share a common substrate is not surprising: Judith Olszowy-Schlanger demonstrated over twenty years ago that the main body of the Qaraite ketubbah formulary seems patterned mainly on Iraqi-Rabbanite non-ketubbah legal documents. ${ }^{36}$ Comparison to Halper 331 suggests, however, that Qaraite ketubbot were not simply (or at any rate not exclusively) modeled on contemporary (tenth-century and later) Iraqi-Rabbanite exemplars. Rather, features of the Qaraite ketubba prologues - even novel formulae that first surfaced in these prologues well into the eleventh century-derive from an older and otherwise unknown repertoire of document prologue formulae, from which IraqiRabbanite ketubba prologues drew separately. Echoes of this prologue tradition are found outside the Genizah too, in many later ketubbot that include superscriptions with מימן טוב ('a), מוב good sign'), מזל טוב ('a good constellation'), and variants. ${ }^{37}$

All this points overwhelmingly to an eastern-likely Iraqi-diplomatic context for Halper 331 , rather than a Syrian-Palestinian one. An eastern identification is also supported by comparison to T-S Ar. 38.11, a rare surviving early medieval Iraqi ketubbah produced in Baghdad sometime between 889 and $988 .{ }^{38}$ Like Halper 331, this ketubbah combines a Hebrew prologue with an Aramaic main text - a combination unusual in Egyptian and Syrian ketubbot before the mid-eleventh century. ${ }^{39}$ Unfortunately, its prologue is too effaced to be fully legible, but it may well reflect yet another repertoire of related formulae to those known from other Geniza ketubbot: it appears to begin with the word בשעה ('in a time,' or perhaps ישע, 'salvation') and to end with והצלחה, 'and prosperity.'

But does Halper 331 contain the text of a ketubbah? In 'classical' (tenth-century and after) Genizah documents, the prologues we have just surveyed are a characteristic feature of ketubbot. They almost never appear in documents of other kinds (except in Qaraite betrothal

\footnotetext{
${ }^{35}$ The fact that Palestinian-Rabbanite and Qaraite ketubbot both begin with an invocation of God's name is likely incidental, since this practice was extremely widespread in Egypt and Syria beyond the context of Jewish documents; see below, at n. 42.

${ }^{36}$ Karaite Marriage Documents, 131-134. As M. A. Friedman has pointed out, however, they include some elements characteristic of Palestinian-Rabbanite ketubbot: see idem, 'On the Relationship of the Qaraite and the Palestinian Rabbanite Marriage Contracts from the Geniza,' Te'uda 15 (1999): 153-156 [Hebrew].

${ }^{37}$ See, e.g., the examples cited in S. Sabar, 'Words, Images, and Magic: The Protection of the Bride and Bridegroom in Jewish Marriage Contracts,' in Jewish Studies at the Crossroads of Anthropology and History, ed. R. Boustan et al. (Philadelphia, 2011), 102-132.

${ }^{38}$ See above, n. 6 . There are also Iraqi gaonic ketubba formularies, but they omit the document prologues that are our focus here, likely because these were not considered integral to the contract's legal efficacy. See R. Brody and M. Ben-Sasson, Sefer ha-Shetarot le-Rasa'g (forthcoming); S. Assaf, Sefer ha-Shetarot le-Rav Hayya ben Sherira Ga'on (Jerusalem, 1930).

${ }^{39}$ Excepting the use of Hebrew verses in Palestinian-Rabbanite ketubbah prologues.
} 
contracts, which contain the same prologue types as Qaraite ketubbot) ${ }^{40}$ But why this should be the case is not self-evident. Outside the Hebrew-script context, for example, late Byzantine and Islamic-era Egyptian and Syrian legal documents of all kinds routinely opened with an invocation of God's name, beginning in the sixth century with Greek and Coptic Christian documents and continuing in Arabic Islamic ones. ${ }^{41}$ The appearance of such invocations in Palestinian-Rabbanite and Qaraite ketubbot is unsurprising within this documentary landscape; it is rather their absence from most other Jewish legal documents that requires explanation. ${ }^{42}$ Although we know little about the comparable textual landscape in which Iraqi Jewish documents developed, phrases of the sort that appear in Halper 331 may well originally have appeared in other types of documents and literary texts before eventually becoming attached exclusively to ketubbot.

We have thus far identified two manuscripts that support this possibility, and the Genizah corpus may well contain other such texts that we have not yet identified. The first is, like Halper 331, a legal document: a draft or copy of a partnership contract from 987 (perhaps produced as a writing exercise) that quite unexpectedly contains the superscription טבא , 'with a good sign." ${ }^{33}$ The second is not a document at all, but a lectionary containing readings from the Prophets (haftarot) that features several colophons, including one dated $924 .{ }^{44}$ A fragmentary inscription to the left of this dated colophon, apparently a later addition to the manuscript in a different hand, reads על [...' עליו ועל בניו אחריו סימן יפה ועונה מהוללה אמן on him and on his sons after him, a good sign and an exalted season, amen' - a partial parallel to Halper $331 .{ }^{45}$ What this phrase means here is not precisely clear, but the ending 'amen' suggests it is a liturgical notation of some kind; and indeed, immediately below it, there is another such liturgical note in yet another hand, giving instructions in Judeo-Arabic and Hebrew about a Sabbath prayer. ${ }^{46}$ This lectionary further underscores the complex textual landscape in which such invocations appear to have functioned and from which the ketubbah superscriptions emerged, a landscape in which Iraqi and Palestinian elements were closely intertwined. The lectionary's main body is paleographically Palestinian and follows a Palestinian triennial cycle; but the Judeo-Arabic prayer note that appears immediately below our inscription is for an Iraqi-rite Sabbath prayer, and a different entry elsewhere in the manuscript paraphrases the Babylonian Talmud. ${ }^{47}$

\footnotetext{
${ }^{40}$ Qaraite betrothal contracts: these are included in Olszowy-Schlanger, Karaite Marriage Documents (see, e.g., ibid., nos. 4, 5, and 6). Iraqi-Rabbanite betrothal and other pre-marital contracts, which date only to a later period (beginning in the early twelfth century), occasionally feature a short prologue (or versions of similar formulae included at the end of the contract), but these are not standard. See A. Ashur, 'Engagement and Betrothal Documents from the Cairo Geniza' (Hebrew. PhD diss., Tel Aviv University, 2006), 46.

${ }^{41}$ See the recent survey, including references to past studies, in L. Berkes, 'Writing Exercises from Early Islamic Bawit,' in New frontiers of Arabic papyrology: Arabic and multilingual texts from early Islam, ed. S. Sobhi et al. (Leiden, 2017), 32-34.

42 Jewish legal documents from the classical Genizah period do occasionally include a basmala, but this is rare and idiosyncratic. In contrast, Genizah letters and petitions often begin with a basmala, as do contemporary literary texts.

${ }^{43}$ T-S 12.710, ed. P. Ackerman-Lieberman, 'A Partnership Culture: Jewish Economic and Social Life Seen Through the Legal Documents of the Cairo Geniza' (PhD diss., Princeton University, 2007), 114-116.

44 T-S A 42.2.

45 The phrase 'in an exalted season,' which is absent from Halper 331, appears in at least one much later ketubbah preserved in the Genizah: T-S $18 \mathrm{~J}$ 1.4, dated 1094.

46 It begins: ופי אלסבת יקול הנח לנו כי אבינו אתה ('And on the Sabbath he should say: Grant us rest, for you are our father ...'). On the Iraqi-Rabbanite prayer הנח לנו כי אבינו אתה, see S. Reif, Jewish Prayer Texts from the Cairo Genizah (Brill: Leiden, 2016), 126.

${ }^{47}$ On this manuscript's palaeography, see J. Olszowy-Schlanger, 'The Anatomy of Non-biblical Scrolls from the Cairo Geniza,' in Jewish Manuscript Cultures: New Perspectives, ed. I. Wandrey (Berlin: de Gruyter, 2017$), 78$.
} 
Invocations like those that appear in Halper 331 were not always, then, exclusive to ketubbot. Still, it remains possible that Halper 331 was in fact marriage-related. The strongest hint to this effect lies in the fragment's use of Psalms 135:21. This is counter-intuitive, because Psalms 135:21 appears rarely in Genizah ketubbot. But its reference to Jerusalem not only resembles the frequent (and unsurprising) such references in Qaraite ketubbot; a practice of invoking Jerusalem at weddings is mentioned already in the Babylonian Talmud. ${ }^{48}$ Still, this is hardly conclusive. In the absence of further evidence, we cannot be entirely certain that Halper 331 was a ketubbah and not a different kind of legal document.

\section{The Seleucid era}

The reckoning or era in our text's dating clause can only be Seleucid; 1182 SE corresponds therefore to $870 / 1 \mathrm{CE}{ }^{49}$ This makes Halper 331 not only one of the oldest dated documentary texts known from the Cairo Genizah, but also the Genizah's earliest attestation of the Seleucid era.

It is closely followed by another manuscript from the Cairo Genizah, dated to the year 1215 ( $\mathrm{SE}=$ 903/4 CE); significantly, its stated place of writing was not Fusțāt (or Cairo), but Gunbad i-Mallgān, i.e. modern Dogonbadan (Gachsārān), in south-western Iran. ${ }^{50}$ The Seleucid era does not appear after that in the Cairo Genizah until the mid $10^{\text {th }}$ century, from which time onwards it is used in Fustạt as the main, and almost the only, dating method. The earliest examples we know are legal documents that were written in Fusțât and dated to the 1260s of the Seleucid Era (=950s CE); the earliest marriage contracts from Fusțāt with Seleucid dates are from the $1290 \mathrm{~s}$ SE $(=980 \mathrm{~s} \mathrm{CE}) .{ }^{51}$ In these documents, the Seleucid era is either implicit or explicitly mentioned as מנין שטרות, 'reckoning of contracts'.

\footnotetext{
The colophon and two liturgical notations are on the page of the shelf-mark labelled " $1 r$ " by the holding library. The talmudic paraphrase appears on $2 \mathrm{v}$. It closely parallels bBava Batra 15a, a famous passage ascribing the authorship of various biblical books to specific biblical figures.

48 bBava Batra 60b.

${ }^{49}$ The era of Destruction (see below) would take us to the $13^{\text {th }}$ century CE, which is palaeographically excluded.

50 T-S NS 246.26.2, a fragment of Bible (the end of the book of Nehemiah) with Babylonian pointing, with a dated colophon. Although the year is not explicitly stated as of the Seleucid era, on palaeographic and historical grounds this seems like the only possible interpretation; the date is therefore equivalent to 903/4 CE (see H. P. Rüger, 'Ein Fragment der bisher ältesten datierten hebräischen Bibelhandschrift mit babylonischer Punktation', Vetus Testamentum 16 (1966) pp. 65-73; M. Beit-Arié, C. Sirat, and M. Glatzer, Codices Hebraicis litteris exarati quo tempore scripti fuerint exhibentes, vol.1, Turnhout: Brepols, 1997, no.2, pp. 40-1). This fragment has been claimed as the 'oldest dated medieval Hebrew manuscript' (https://cudl.lib.cam.ac.uk/view/MS-TS-NS-00246-00026-00002, accessed 20 July 2018) - a claim that may well be justified. Another Bible manuscript (of the latter Prophets), Ms St Petersburg RNL EVR.II B 100, has a colophon (on fol. 50v) dated year 1205 'of the Greek reckoning' (= 893/4 CE) and located in 'Egypt' (presumably Cairo), but this colophon is surely a forgery. The manuscript itself, which is not listed or even mentioned in Beit-Arié et al., Codices Hebraicis, is evidently late (as has been confirmed to us by Judith Olszowy-Schlanger on palaeographical grounds, and by Ben Outhwaite on orthographic and texual grounds); and the colophon's reference to Saadya Gaon is blatantly anachronistic.

${ }^{51}$ The earliest documents written in Fusțāt and dated by the Seleucid era are: 1. T-S 20.85, 126? SE (948-959 CE); 2. Bodl. MS Heb. b. 12.6 + b. 12.29 (ed. S. Assaf, 'Old Genizah Documents from Palestine, Egypt and North Africa', in Tarbiz 9 (1937) pp. 11-34 [Hebrew],no. 14; 959 CE); 3. T-S 12.539 (965 CE); 4. T-S 12.462, a late 10 ${ }^{\text {th }}$ or early $11^{\text {th }}$-century endorsement of a deed of sale of a property in Fusțāt that was dated Monday 22 Tevet, 1277 SE (= 18 December 965 CE). 5. T-S 12.515, an acknowledgment of debt in Fusțāt dated Thursday 12 Siwan, 1278 (presumably SE, = 23 May 967 CE). The earliest marriage contracts from Fusțāt with Seleucid era
} 
Especially because our document's provenance is unknown, its much earlier use of the Seleucid era raises questions about its place of composition. The location clause, which would normally appear after the date, is not preserved; but there is no reason to assume that it necessarily in Egypt. The document from which our fragment was copied-and perhaps even the fragment itself - could have been drafted somewhere in the east, like the nearly contemporary, Seleucid-era dated manuscript from Gunbad i-Mallgān.

The reason for raising this suspicion is that the Seleucid era was not native to Egypt. The Seleucid era drew its origins, in the late $4^{\text {th }}$ century BCE, in the territories of the Seleucid Empire, where it had a long history and remained in use long after the Empire's end, especially among Christians and Jews, throughout late antiquity and the medieval period. Its Jewish use and its computation are thus discussed at length in a passage of the Babylonian Talmud (bAvodah Zarah 9a-10a), where the assumption is made that this is the era normally used by scribes, and where the statement is made that 'in the Exile, one only reckons according to the Greek kings';52 the term 'Exile', in the Babylonian Talmud, usually means Babylonia. ${ }^{53}$ The Seleucid era is also well attested in Babylonian Gaonic literature of the early Islamic period, such as the Gaonic responsa, the exilarch's letter of 835/6, and the chronographic Epistle of Sherira Gaon of 986/7 CE. ${ }^{54}$

Egypt, however, had never been part of the Seleucid Empire, and its dating systems had always been quite different. In the Roman and Byzantine periods, dates were given most commonly in regnal years (of the Roman emperors) and Roman consular dates. After the Arab conquests, these were abandoned in favour of the Hijri era (beginning in $622 \mathrm{CE}$, and based on the Islamic calendar), but Christians also started to use, for dating purposes, the era of Diocletian (or era of the Martyrs, beginning in $284 \mathrm{CE}$, and based on the Julian calendar). ${ }^{55}$

The Jews of Egypt in antiquity, accordingly, only used regnal and (very rarely) consular years. The Aramaic marriage contract of Antinoopolis, $417 \mathrm{CE}$, is dated according to the consular year; in addition, it includes the year number within the sabbatical cycle. The sabbatical cycle year, a specifically Jewish dating practice, is also attested in late Roman Palestine, and is probably of Palestinian origin, as agricultural sabbatical laws were associated with the land of Israel and thus probably only observed in Palestine. ${ }^{56}$

dates are dated 1297 SE (= 986 CE: T-S 16.105) and 1306 SE (= 994/5 CE: T-S 16.70). Another marriage contract from Fusțāț, T-S 16.189, may be earlier and closer in time to ours, as what remains of its date indicates the $13^{\text {th }}$ century of the Seleucid era, thus any date between about 890 and 990 CE; it is edited by Goitein, 'Four Old Marriage Contracts', pp. 213-15.

52 This statement is attributed to Rav Nahnan ( $3^{\text {rd }}$ century CE, Babylonian); whilst the redaction of the Babylonian Talmud is generally dated to no later than the $6^{\text {th }}$ century. This passage has no parallel in Palestinian rabbinic sources.

${ }^{53}$ bRosh ha-Shanah 23b: 'the 'Exile' - this is Pumbaditha'.

${ }^{54}$ Exilarch's letter: reference above, n. 6.

${ }^{55}$ R. S. Bagnall and K. A. Worp, Chronological systems of Byzantine Egypt, 2nd edn., Leiden: Brill, 2004, especially pp. 43-35 (regnal years), 88-98 (consular years), 63-87 (era of Diocletian), 300 (Hijri era); and on indictions, pp. 7-35.

${ }^{56}$ Marriage contract of Antinoopolis: C. Sirat, P. Cauderlier, M. Dukan, and M. A. Friedman, La Ketouba de Cologne. Un contrat de mariage juif à Antinoopolis (Papyrologica Coloniensia 12), Köln, 1986. The Sabbatical cycle year is used in the contemporary (late $4^{\text {th }}-$ early $6^{\text {th }}$ centuries) funerary inscriptions from Zoar (Palestina Tertia): see Y. E. Meimaris and K. I. Kritikakou-Nikolaropoulou, Inscriptions from Palaestina Tertia, vol. ic: The 
In the early Islamic period, there is little or no evidence of how the Jews of Egypt reckoned the years. The Hijri era was available and most probably used (it is attested in later Jewish sources), but its years had the disadvantage of being incompatible with the year length of the Jewish calendar. ${ }^{57}$ The era of the Martyrs was probably too explicitly Christian for Jews to be willing to use it. This may explain why, at least from the late $9^{\text {th }}$ or early $10^{\text {th }}$ century, two new, and specifically Jewish, dating systems become evident in Egypt.

The first is the era of the Creation (a form of Anno Mundi), whose starting point (in the Jewish Palestinian tradition) was 3761 BCE. The partnership contract of 875 or $876 \mathrm{CE}$ (T-S C 2.17), mentioned above, is thus dated according to the era of Creation; it appears in a manuscript of the Cairo Genizah, and could well have originated from Egypt. Later, an explicitly Egyptian marriage contract, from Qugandima (eastern Nile Delta), is dated Thursday $16 \mathrm{Av}, 4705$ of this era $(945 \mathrm{CE}) ;^{58}$ and in the later $10^{\text {th }}$ century, the Creation era is attested in other Egyptian localities around the Nile Delta. ${ }^{59}$ This era begins to be used in documents from Fustạt in the late $10^{\text {th }}$ century CE. ${ }^{60}$ The era of Creation was possibly also of Palestinian origin. Although it is also attested in the Babylonian Talmud (bAvodah Zarah 9b), there is very little evidence of its use in Babylonia before the $11^{\text {th }}$ century; whereas it is attested in late antique Susiya, southern Judaea, in a Hebrew inscription in the mosaic pavement of the synagogue. ${ }^{61}$ This era later became the most commonly used by Jews in medieval Europe and elsewhere until today.

The second is the era of the Destruction (of the Jerusalem Temple, in $70 \mathrm{CE}$ ), whose starting point varies, but tends to be 68/9 CE (sometimes 67/8). This era is attested in the colophon of a Haftarot lectionary based on the Palestinian triennial cycle, which is dated Thursday $18 \mathrm{Av}$

Jewish Aramaic Inscriptions from Ghor Es-Safi (Byzantine Zoora) (Meletemata, 73; Athens: National Hellenic Research Foundation), 2016.

${ }^{57}$ A possible example of early Jewish use of the Hijri era is p.Ragab 34, a deed of sale of a mule belonging to a Jew, apparently dated $144 \mathrm{AH}$ (= 761/2 CE): A. Hanafi, 'Two unpublished paper documents and a papyrus', in P. A. Sijpesteijn and L. Sundelin (eds.), Papyrology and the History of Early Islamic Egypt, Leiden: Brill, 2004, pp. 45-61, on pp. 56-60. The designation of the owner as 'Jew' suggests that the purchaser was non-Jewish, which may explain in this case why the Hijri era was used. Hanafi takes the absence of the basmala as an indication that the author of the document may have been Jewish, although this is not conclusive.

${ }^{58}$ T-S 12.154: Goitein, 'Four Old Marriage Contracts', pp. 208-13; Friedman no.14 (ii. 165-75). It appears not to have been noted that this date is problematic, as according to the rabbinic calendar, 16 Av 4705 AM fell not on a Thursday but on a Tuesday, 29 July 945 CE. A two-day error seems unlikely, but I have no other way of accounting for it. It cannot be explained, for example, if we assume that the 'eastern' or Babylonian era of Creation, with an epoch in $3760 \mathrm{BCE}$, was used.

${ }^{59}$ From Tinnīs (east of the Nile Delta): Bodl. MS Heb. a.2.3 a-c, 989 CE. From Bunā (Nile Delta): T-S 16.132, 998 $\mathrm{CE}$, with both the Creation and the Seleucid eras.

${ }^{60}$ The only examples I know from Fusțāt in the $10^{\text {th }}$ century (last two decades) are documents that were possibly written by the same scribe: T-S 16.221 and T-S NS 323.34, dated by both the era of Creation and the Seleucid era, 986 CE; T-S 16.175, both eras, 990s CE; and T-S AS 145.52 verso, era of Creation only, 994 CE. On this scribe ('Scribe IV'), see Olszowy-Schlanger, 'On the graphic cultures' ( $n$. 62 below). But the use of both the Seleucid and the Creation eras becomes common in Hebrew documents from Fusțāt in the early $11^{\text {th }}$ century (e.g. T-S 24.11, from 1002 CE); whereas Judeo-Arabic documents continue to be dated by the Seleucid era only. The subsequent history of these eras in Fusțāt is yet to be charted.

${ }^{61}$ Z. Yeivin, 'Susiya: The Synagogue', in E. Stern et al. (eds.), New Encyclopaedia of Archaeological Excavations in the Holy Land, 4 vols., Jerusalem: Israel Exploration Society, 1993, iv: 1417-1421. The inscription is difficult to date, because only the number 4000 is preserved, but the synagogue as a whole was built and repaired in several stages between the $4^{\text {th }}-8^{\text {th }}$ centuries, so this inscription could be quite early. The sabbatical cycle year also appears in this inscription. 
856 'of the era of the Temple' (=22 July $924 \mathrm{CE}$ ); it was found in the Cairo Genizah, and its provenance may well have been Egypt. ${ }^{62}$ In the mid $10^{\text {th }}$ century, a Bible colophon written in Gaifa (near Bilbeis, north-east of Cairo) is dated to the year 886 of the same era (=953/4 CE). ${ }^{63}$ The era of Destruction is known as a Palestinian tradition going back to late Antiquity, as it is used pervasively in the $4^{\text {th }}-6^{\text {th }}$-centuries Jewish tombstones from Zoar. ${ }^{64}$

The introduction of the Seleucid era in Fustạt, which is visible in the Genizah from the second half of the $10^{\text {th }}$ century onwards (but may have occurred earlier), was most probably due to Jewish Babylonian emigration westwards, which is known to have impacted Jewish society and culture in Fustạat in many other ways. ${ }^{65}$ Judith Olszowy-Schlanger has recently argued, on the basis of palaeographic evidence, that nearly all the earliest (late $10^{\text {th }}$-century) legal documents from Fustạt preserved in the Genizah are written in a Babylonian script, and Eve Krakowski is currently working on a study demonstrating that their structure and formulae likewise resemble Babylonian gaonic models. ${ }^{66}$ Both conclusions tally with the observation that these legal documents are all dated according to the Seleucid era, a Babylonian tradition, and indeed, that the attestation of the Seleucid era in late $10^{\text {th }}$-century Fustạat is confined entirely to such legal documents.

If our document originated indeed from the Cairo Genizah, and if, furthermore, it was locally produced, then its employment of the Seleucid era would offer evidence that the Seleucid era was in use in Fustât already by 870 or 871 , nearly a century before the earliest of these tenthcentury documents. On the other hand, there are many reasons to suspect that the document (or more minimally, the text from which it was copied) may rather have originated east of Egypt and Palestine: its use of a Babylonian vowel (on the last line of the text extant), its apparently Iraqi introductory formulae (as argued above), and its early use of the Seleucid era. ${ }^{67}$ Analysis of the rest of the date, as we shall now see, may point further in this direction.

\footnotetext{
62 T-S A42.2; see Beit-Arié et al., Codices Hebraicis, no.4, pp.48-52. This document just postdates the period, in 922-3 CE, when Babylonian and Palestinian Rabbanite calendars differed.

${ }^{63}$ MS Manchester John Rylands University Library, Gaster Genizah 2; Beit-Arié et al., Codices Hebraicis, no.9, pp. 80-1.

${ }^{64}$ See above, n.52. The era of Destruction is also attested in several early $9^{\text {th }}$-century Hebrew funerary inscriptions in Venosa, Italy (most recently re-edited by Leonard Rutgers and Ortal Paz-Saar,

https://diaspora.sites.uu.nl/projects/3d-pilot-project-in-venosa/, accessed 9 August 2018). Its use in Egypt, in the $10^{\text {th }}$ century and later, remained however sporadic.

${ }^{65}$ See for example Friedman, Jewish Marriage in Palestine, vol. 1: 21-30.

$66 \mathrm{~J}$. Olszowy-Schlanger, 'On the graphic cultures of the beit din: Hebrew script in legal documents from Fustat in the early Fatimid period', in A. Salvesen, M. Frenkel, and S. Pearce (eds.), *** in Egypt, Leiden: Brill, forthcoming, $* * *$.

${ }^{67}$ Another feature of our ketubbah that identifies it as 'Babylonian' rather than 'Palestinian' or western is that the day of the month is given before the name of the month (whereas in Palestinian ketubbot, the month name is mentioned first: Friedman, Jewish Marriage in Palestine, i.102-7; Olszowy-Schlanger, Karaite Marriage Documents, 160-3). The Seleucid era was similarly alien to the Palestinian tradition, and Palestinian marriage contracts continued, in the $11^{\text {th }}-12^{\text {th }}$ centuries, to be dated according to the eras of the Destruction or of the Creation, often together with the sabbatical year (Friedman, ibid.; Olszowy-Schlanger, ibid.). However, even within the Palestinian tradition, the Seleucid Era made significant inroads from the late $10^{\text {th }}$ century onwards. Thus, the colophon of a manuscript written in Jerusalem by a Maghrebi scribe is dated 1300 'of the kingdom of the Greeks' (988/9 CE: Ms St Petersburg RNL EVR.II B 39, fol. 156v, Beit-Arié et al., Codices Hebraicis, no.12, pp. 88-97); and several $11^{\text {th }}$-century and later Palestinian-type ketubbot from outside Palestine, in particular from Damascus, are dated by the Seleucid era (Friedman, Jewish Marriage in Palestine, i.106 and n.34, ii. nos. 27 and 56). The only attested Palestinian-type ketubbah that was written in Fusțāt, in $1007 \mathrm{CE}$, is dated by both the era of Creation and the Seleucid era (T-S 18J1, fol.3; ibid. ii. No. 50, pp. 376-83). The use of the Seleucid era
} 


\section{$\underline{\text { A sectarian date? }}$}

Our document's date is given as Friday, 17 Tishri, year 1182 SE; but in terms of the rabbinic calendar, it is very problematic. Firstly, it is incorrect, as according to the rabbinic calendar, 17 Tishri of that year fell on 16 September 870 CE, a Saturday. ${ }^{68}$ Secondly, this date is impossible, because it implies that 1 Tishri (the New Year) fell on Wednesday, which the rabbinic calendar does not allow. ${ }^{69}$ In whichever year it falls, a date such as this would never be possible.

Yet if this discrepancy from the rabbinic calendar is put down to error, as Goitein and others assumed, it is difficult to establish what the error was, or how this date could be plausibly corrected. In a Jewish document, an error is generally unlikely to occur with the day of the week, especially in close proximity to the Sabbath. But even if the day of the week is in need of correction here, the original contract could not have been written on a Saturday (17 Tishri, 16 September 870), when writing is prohibited.

A better option, therefore, is to assume that the day of the month is erroneous. Assuming that the day of the week was Friday, as stated, the correct date must then have been Friday 16 Tishri. But this is also problematic, because in Egypt, the Rabbanites celebrated 16 Tishri as the second day of Sukkot, the festival of Tabernacles, on which it was similarly forbidden to write contracts. $^{70}$

Unless the date of this contract is wildly wrong - for example, the name of the month is wrong, or the month (Tishri) is right but the day of the month was totally different ${ }^{71}-$ the possibility of another calendar, non-rabbinic or even non-Jewish, should be considered. Here again, however, the options of limited. The only non-Jewish calendar at the time that employed the month name of Tishri was the Syrian calendar, which has two months by that name: Tishrin I, equivalent to October, and Tishrin II, November. In $870 \mathrm{CE}, 17$ Tishrin II (17 November) fell on a Friday. But if our contract were dated according to the Syrian calendar, the date should have specified which of the two Tishrin was meant. It seems unlikely, besides, that a Jewish marriage contract - if this is what it is - of the $9^{\text {th }}$ century was dated according to a non-Jewish calendar.

\footnotetext{
was also prominent among the Qaraites from the late $10^{\text {th }}$ century onwards (Olszowy-Schlanger, Karaite Marriage Documents, 160-3).

${ }^{68}$ Halper's reading of '1183', which has been dismissed above as incorrect, does not afford a solution, as in that year too 17 Tishri fell on a Saturday.

${ }^{69}$ This rule is attested already in the Palestinian Talmud (late $4^{\text {th }}$ century), and by the $9^{\text {th }}$ century was very well established in the rabbinic calendar. See Stern, Calendar and Community, pp. 166-7, 171, 194-5. This rule is taken for granted, for example, in the Exilarch's letter of 835/6 CE (ibid. 277-83, and see above, n. 6). See further above, n.1.

70 If our document is a ketubbah, it would also be pertinent to note that marriages on Friday were unusual (Friedman, Jewish Marriage, vol.1: 99, n.6); and moreover, it is strange for a marriage to have been scheduled in the middle of the festival season of Tishri.

${ }^{71}$ In order to match a Friday, there are actually not many options available within the month of Tishri $870 \mathrm{CE}$, as many of the other Fridays in that month coincided with festivals ( 2 Tishri, 23 Tishri) or with the eve of the day of Atonement (9 Tishri), which were equally unsuitable for marriage or for writing contracts. The only option would be Friday 30 Tishri, the last day of the month. It is almost inconceivable that 17 was substituted by mistake for 30 .
} 
Turning to non-rabbinic, Jewish calendars, the Qaraite calendar immediately comes to mind. By the late $9^{\text {th }}$ century, the Qaraite movement was emerging and gaining strength in the Jewish Near East. It is generally assumed that the Qaraites rejected the fixed rabbinic calendar, and advocated instead an empirical calendar based on monthly sightings of the new moon. In most cases, however, this had the effect of starting the month one or two days after the rabbinic month (as the rabbinic month normally begins at the astronomical new moon, i.e. the lunar conjunction, before the new moon becomes visible). This was indeed the case in this year. The new moon was first visible in Egypt and the Near East on Thursday evening, 31 August $870 \mathrm{CE}$, which means that day 1 of the Qaraite Tishri could not have been earlier than Friday 1 September. Consequently, 17 Tishri would have fallen on Sunday, which is too late for our purposes and does not match the date of our document.

The date of our document does match, however, another Jewish calendar of this period, that of the followers of Abū 'Imrān al-Tiflīsì. This sectarian leader, together with Ismā '̄il al'Ukbarī (both active in the early-mid $9^{\text {th }}$ century), are said by Jacob al-Qirqisānī (early-mid $10^{\text {th }}$ century) to have determined the month on the basis of the 'birth of the new moon', i.e. the molad (lit. 'birth') or lunar conjunction that was also used by the Rabbanites in their calendar calculation. ${ }^{72}$ They differed, however, from the Rabbanites in that they did not apply any postponement rules (to prevent the New Year from falling on Sunday, Wednesday, or Friday), but rather always began the month at the time of, or on the day of, the lunar conjunction. ${ }^{73}$ A similar account is given by Yefet ben Eli (mid-late $10^{\text {th }}$ century) in his Bible commentaries. On Genesis 1:13-15, he writes that Abū 'Imrān al-Tiflīsī and his followers calculated the calendar on the basis of the conjunction, whereas the Rabbanites did so on the basis of the molad - the distinction between the two concepts is not clarified. ${ }^{74}$ On Leviticus 23:4-8, he writes that both the Rabbanites and al-Tiflisi follow the molad, but sometimes the Rabbanites postpone the month from one day to the other, whereas al-Tiflisin does not make any postponements. ${ }^{75}$ The distinction in this passage is very clear, and agrees with the account of al-Qirqisān̄.

The lunar conjunction (or molad) of Tishri $870 \mathrm{CE}$, according to the rabbinic calendar calculation, was on Wednesday (30 August), 16 hours (i.e. shortly before noon) and 589 parts (of the hour divided in 1080 parts). Since the rabbinic calendar does not allow the New Year to fall on Wednesday, 1 Tishri was postponed to Thursday. But the followers of al-Tiflīsi would have kept the New Year on the same Wednesday; and consequently, their 17 Tishri would have fallen on Friday, exactly as in the dating of our legal document. This raises the possibility that it was drawn up by non-rabbinic Jews, who observed a calendar such as that of al-Tiflīsī.

\footnotetext{
72 Jacob al-Qirqisānī, Kitāb al-anwār wa-al-marāqib, 1:15-16, in English translation in L. Nemoy, 'Al-Qirqisānī's account of the Jewish sects and Christianity', Hebrew Union College Annual 7, 1930, pp. 317-97, on pp. 388-9; text in id., Kitāb al-anwār wa-al-marāqib: Code of Karaite law, by Ya'qūb al-Qirqisānī, New York: Alexander Kohut Memorial Foundation, 1939-43. Qirqisānī defines the molad as the time of the moon's 'separation' from the sun; this definition is unusual, but Qirqisāni probably means the end of the moon's conjunction with the sun.

${ }^{73}$ Ismāīl al-'Ukbarī: 'at the time of'; Abū 'Imrān Al-Tiflīsī: 'on the day of' (al-Qirqisānī, ibid.).

${ }^{74}$ Ms St Petersburg IOS, B051, fol.36r, as transcribed by M. Zawanowska, The Arabic Translation and Commentary of Yefet ben Eli the Karaite on the Abraham Narratives (Genesis 11:10-25:18), Leiden: Brill, 2012,


חסאבה עלי אלאגתמאע והע והו אבו עמראן אלתפליסי ואצחאבה. ואלב' חסאב אלרבאנין והו חסאב מבני עלי אלמילאד. ${ }^{75}$ Ms St Petersburg RNL, Evr.-Ar. I 73, fol. 99v (a manuscript copied in 594 AH, 1198 CE). Later text witnesses include $\mathrm{ms}$ London BL, Or.2518, fol. 5 r.
} 
Although al-Tiflīsī himself was apparently based in Georgia, not enough is known about his life and his movement to dismiss the possibility that a document drawn up in his circle - or more precisely, a copy of such a document — ended up in the Cairo Genizah. This is especially so as, judging by Qirqisānī's account, he was probably not the only non-Rabbanite to advocate a calendar of this kind. However, as argued above, many features of this legal document point to its having been composed east of Egypt and Palestine. This would bring it closer to regions were non-Rabbanite circles such as al-Tiflīsî̀'s were particularly active. ${ }^{76}$

The identification of our ketubbah - if indeed it is one - as non-Rabbanite, and (in a strict sense) non-Qaraite, would be remarkable and quite unique. But we must be cautious not to label such a document, for this reason, as 'sectarian'. Besides being inherently problematic, the category of 'sectarian' does not characterize appropriately the tremendous fluidity of nonRabbanite movements in the late $9^{\text {th }}$ century. ${ }^{77}$ Moreover, it is entirely conceivable that a Rabbanite author of this formulary - if this is what the fragment was part of - copied the text of this document as a model without realizing, from its date, that it did not conform to the rabbinic calendar and that it must have emanated, therefore, from non-Rabbanite circles. In all other respects, this contract may have conformed entirely to rabbinic law, and may therefore have been suitable for inclusion in the formulary.

The document before us, even if not the 'oldest dated document of the Cairo Genizah,' is nonetheless evidently very old. It belongs to a period when the method of calendar calculation, along with other matters that were later to become certainties, were still rather uncertain in learned circles of the Jewish Near East. Whilst it is difficult to draw any firm conclusions from the formulae and date that appear in this very short text, this document has clearly much to teach us about time reckoning, the Jewish calendar, and more generally the diversity of Jewish practices in the $9^{\text {th }}$ century CE.

\footnotetext{
${ }^{76}$ Doubts can also be expressed as to the Cairo Genizah provenance of this fragment, as has been pointed out above.

77 See M. Rustow, 'The Qaraites as sect: the tyranny of a construct', in Sects and Sectarianism in Jewish History, ed. S. Stern (Leiden: Brill, 2011), 149-86.
} 